\title{
MEASLES ANTIBODY PREVALENCE AFTER MASS IMMUNIZATION CAMPAIGN IN NITERÓI, STATE OF RIO DE JANEIRO, BRAZIL.
}

Solange A. OLIVEIRA (1), Marilda M. SIQUEIRA (2), George F. MANN (2), Antônio José L. COSTA (3), Maria Teresa C.N. ALMEIDA (3), Mônica S. STAVOLA (3), Hugo TOMASINI (3) \& Jussara P. NASCIMENTO (2)

\begin{abstract}
SUMMARY
Three months after a mass vaccination campaign (coverage: 100\%) against measles a random seroepidemiological survey was carried out in students aged 1 to 19 years old in the Municipality of Niterói, State of Rio de Janeiro. Blood samples were tested for measles antibodies by enzyme immunosorbent assay (EIA) and negative cases were tested again using hemagglutination inhibition (HI) and plaque reduction neutralization (PRN). Of the 798 samples tested by EIA, $718(90.2 \%)$ were positive for measles antibodies. PRN test was more sensitive than EIA and $\mathrm{HI}$ in detecting measles specific antibodies. The total antibody prevalence increased from $90.2 \%$ to $93.2 \%$ when $\mathrm{HI}$ was employed in EIA negative specimens and to $98.9 \%$ when PRN was used. After the mass vaccination campaign a marked decrease in measles incidence was observed in the municipality studied, showing the effectiveness of the strategy used for measles control in developing countries.
\end{abstract}

KEYWORDS: Measles; Vaccination; Seropidemiological survey

\section{INTRODUCTION}

Despite the introduction of the Brazilian National Immunization Programme in 1973, measles was still a serious public health problem in the early 1992, being one of the leading causes of morbidity and mortality among children below 5 years of age. The difficulty in achieving high coverage rates in routine vaccination led some State Health Departments to introduce periodic measles campaigns during polio mass campaigns. However, this strategy was not implemented for the country as a whole and measles outbreaks continued occurring ${ }^{10}$.

Based on the above, the Brazilian Health Ministry launched a countrywide mass immunization campaign against measles. From 24 April to 22 May / 1992. measles vaccine was given to 48023657 children aged from 9 months to 14 years irrespective of previous vaccination or disease history. The immunization coverage achieved was $96 \%$ of the target population ${ }^{10}$.

Niterói, State of Rio de Janeiro, is one of the greatest cities of this region and in 1992 the estimated population was 436175 inhabitants? $^{7}$. Until 1984 the epidemiology of measles in the city was characterized by high morbidity and mortality rates, mainly reported in children under five. Since 1985, following the introduction of immunization campaigns mainly directed to children 9-23 months of age,

(1) Disciplina de Doenças Infecciosas and Departamento de Saúde da Comunidade, Faculdade de Medicina, Universidade Federal Fluminense, Niterói, RJ, Brazil.

(2) Departamento de Virologia and Bio-Manguinhos, Fundaçâo Oswaldo Cruz, Rio de Janeiro, RJ, Brazil.

(3) Fundação Municipal de Saúde de Niterói, RJ, Brazil.

Correspondence to: Dra. Solange Artimos de Oliveira, Disciplina de Doenças Infecciosas e Parasitárias. Rua Marquês do Paraná, $303,2^{\circ}$ andar. 24030-210. Niterói, Rio de Janeiro, Brazil. Fà (021) 719-7262. 
measles incidence and mortality declined rapidly. Measles incidence in Niterói began to increase in 1990, but at this time most cases were observed in teenagers and young adults $^{16.17}$. Following the strategy planned for the whole country, the vaccination coverage achieved during the mass campaign was $100 \%$ of the target populations.

The objective of this study was to estimate the prevalence of measles antibody in the population below 20 years old of this city at three months after mass immunization campaign.

\section{MATERIALS AND METHODS}

Study population

The population in the survey was composed of students resident in Niterói, aged I to 19 years old.

\section{Sampling}

A multiple stage sample design was used ${ }^{13}$. The first stage consisted of a cluster sample of the public and private schools and kindergartens of the city. The selection was proportional to the number of schools within each one of the three Sanitary Districts. For the second stage, a simple random sample of the students within each selected school was made, an average of 216 students per studied age group. To estimate the sample for each District, the results of 1991 census $^{7}$ were adopted, and the selection was proportional to the number of people below 20 years old resident within these sectors. The parents were always asked to consent to the drawing of a blood sample from their children. If they refused, a new random sample was obtained.

The sample was calculated taking in account the characteristics of the sampling process ${ }^{13}$ and the follow- ing parameters: $2.1 \%$ of sampling error. $90 \%$ of estimated prevalence, and a confidence interval of $95 \%$.

\section{Blood sample collection}

Blood samples for serology were obtained by venepuncture. After centrifugation the sera were stored at $-20^{\circ} \mathrm{C}$.

\section{Laboratory tests}

Initially each sample was tested by an enzyme immunosorbent assay (EIA) to detect anti-measles lgG antibodies. This test was described by HUMMEL et al. ${ }^{\text {2" and }}$ it is an indirect IgG EIA that uses a recombinant antigen (measles nucleoprotein). This test employs as cutoff valuc for a positive result the $\mathrm{P} / \mathrm{N} \geq 3$ and $\mathrm{P}-\mathrm{N} \geq 0.09$. Negative samples were tested again using haemagglutination inhibition $(\mathrm{HI})^{14.19}$ and plaque reduction neutralization $(\mathrm{PRN})^{4}$ tests. The children who had $\mathrm{HI}$ titers below 8 and PRN antibody levels of $<50$ milli International Units $/ \mathrm{ml}$ were considered to be potentially susceptible to measles.

\section{Statistical analysis}

Frequency distributions were analysed by the chisquare test and the differences between individual groups considered significant at the 0.05 level.

\section{RESULTS}

Of the 796 samples tested for measles specific antibodies by EIA, $718(90.2 \%)$ were positive. Analysis of seropositivity according to different age groups showed that for children in the $1-4$ age group only $73.1 \%$ were positive. However, an increase in antibody prevalence was observed for the older age groups studied (Table I).

TABLE

Results of the serological tests used in the serum samples of the survey, according to the studied age groups Niterói, RJ. August/1992.

\begin{tabular}{|c|c|c|c|c|c|c|c|c|c|c|c|c|c|}
\hline \multicolumn{14}{|c|}{ Serological Tests } \\
\hline \multirow{3}{*}{$\begin{array}{l}\text { Age Group } \\
\text { (in years) }\end{array}$} & \multicolumn{4}{|c|}{ E I A } & \multicolumn{4}{|c|}{$\mathrm{E} \mathbf{I} \mathrm{A}+\mathrm{HI}^{\mathrm{a}}$} & \multicolumn{4}{|c|}{$\mathrm{E} \mathbf{I} \mathrm{A}+\mathrm{HI}+\mathrm{PRN}^{\prime \prime}$} & \multirow{3}{*}{$\frac{\text { TOTAI }}{\mathrm{N}}$} \\
\hline & \multicolumn{2}{|c|}{ Positive } & \multicolumn{2}{|c|}{ Negative } & \multicolumn{2}{|c|}{ Positive } & \multicolumn{2}{|c|}{ Negative } & \multicolumn{2}{|c|}{ Positive } & \multicolumn{2}{|c|}{ Negative } & \\
\hline & $\mathrm{N}$ & $\%$ & $\mathrm{~N}$ & $\%$ & $\mathbf{N}$ & $\%$ & $\mathbf{N}$ & $\%$ & $\mathrm{~N}$ & $\%$ & $\mathbf{N}$ & $\%$ & \\
\hline $1-4$ & 98 & 73.1 & 36 & 26.9 & 111 & 82.8 & 23 & 17.2 & 129 & 96.3 & 5 & 3.7 & 1.34 \\
\hline $5-9$ & 222 & 92.9 & 17 & 7.1 & 226 & 94.6 & 13 & 5.4 & 238 & 99.6 & 1 & 0.4 & 239 \\
\hline $10-14$ & 252 & 95.8 & 11 & 4.2 & 257 & 97.7 & 6 & 2.3 & 263 & 100.0 & - & - & 263 \\
\hline $15-19$ & 146 & 91.3 & 14 & 8.7 & 148 & 92.5 & 12 & 7.5 & 157 & 98.1 & 3 & 1.9 & 160 \\
\hline Total & 718 & 90.2 & 78 & 9.8 & 742 & 93.2 & 54 & 6.8 & 787 & 98.9 & 9 & 1.1 & 796 \\
\hline
\end{tabular}

" Positive: ElA positive or ElA negative with $\mathrm{HI}$ positive

Negative: EIA and $\mathrm{HI}$ negative

1. Positive: EIA positive; or EIA negative with $\mathrm{HI}$ and PRN positive; or EIA and $\mathrm{HI}$ negative with PRN positive

Negative: EIA negative with $\mathrm{HI}$ and PRN negative 
Of the 78 sera with negative results by EIA. 24 were positive when tested by $\mathrm{HI}$ and 68 when tested by PRN.

Therefore, using both EIA and $\mathrm{HI}$ the total antibody prevalence increased from $90.2 \%$ to $93.2 \%\left(\mathrm{X}^{2}=\right.$ 4.76, $\mathrm{P}<0.05$ ). Although this fact had been observed in all age groups analysed, it was more evident in the 1-4 age group, where the seropositivity increased from $73.1 \%$ to $82.8 \%$ (Table 1). Nevertheless, the chi-squared test showed no significant differences in the four groups studied: $X^{2} 1-4$ years $=3.64, P>0.05 ; X^{2} 5-9$ years $=$ $0.86, \mathrm{P}>0.05: \mathrm{X}^{2} 10-14$ years $=1.50, \mathrm{P}>0.05: \mathrm{X}^{2} 15$. 19 years $=0.16, \mathrm{P}>0.05$.

The total specific antibody prevalence increased from $93.2 \%$ to $98.9 \%$ when PRN test was used in serum samples $\mathrm{HI}$ and EIA negatives $\left(\mathrm{X}^{2}=33.47, \mathrm{P}<0.001\right)$. Thus, employing a more sensitive test, only $9(1.1 \%)$ cases of 796 samples analysed had no anti-measles antibodies.

The increase in seropositivity was also noticed in all age groups studied. However, this fact was clearly evident in the 1-4 age group, where a marked increase $(13.5 \%)$ in antibody prevalence was observed. A rise in seropositivity was also found in the other age groups analysed but the differences were less pronounced (Table 1). These results were statistically significant: $\mathrm{X}^{2} 1-4$ years $=12.90, \mathrm{P}<$ $0.01: X^{2} 5-9$ years $=10.58, P<0.01: X^{2} 10-14$ years $=$ $6.06, \mathrm{P}<0.05 ; \mathrm{X}^{2} 15-19$ years $=5.66, \mathrm{P}<0.05$.

The $95 \%$ confidence intervals calculated taking in account the design of the study are presented in Table 2 .

A hundred EIA positive samples sellected at random were tested by $\mathrm{HI}$ to verify the correlation between both tests employed. The results were also positive and the HI titers varied between $1: 8$ and $1: 128$. However, the majority $(91 \%)$ were between $1: 8$ and 1:32. The $\mathrm{HI}$ titers for the serum samples EIA negative and HI and PRN positive were lower, between $1: 8$ and 1:16.

\section{DISCUSSION}

The results obtained in this study showed that three months after a mass immunization campaign against measles in Niterói, state of Rio de Janeiro, $98.9 \%$ of the people aged from I to 19 years old had detectable measles specific antibodies.

In this study PRN test was more sensitive than EIA and $\mathrm{HI}$ in detecting measles specific antibodies. The total antibody prevalence increased from $90.2 \%$ to $93.2 \%$ when $\mathrm{HI}$ was employed in EIA negative specimens and to $98.9 \%$ when PRN was used.
TABLE 2

Measles antibody seroprevalence according to age after mass vaccination campaign in the municipality of Niteroi, RJ.

August/1992.

\begin{tabular}{ccc}
\hline $\begin{array}{c}\text { Age Group } \\
\text { (in years) }\end{array}$ & $\begin{array}{c}\text { No. of Positives/ Confidence Interval } \\
\text { Total }\end{array}$ & \begin{tabular}{c}
$\boldsymbol{\alpha}=\mathbf{0 . 0 5}$ \\
\hline $1-4$
\end{tabular} \\
\hline $5-9$ & $238 / 134(96.3 \%)$ & $96.3 \% \pm 3.2 \%$ \\
$10-14$ & $263 / 263(100.0 \%)$ & - \\
$15-19$ & $157 / 160(98.1 \%)$ & $98.1 \% \pm 2.1 \%$ \\
Total & $787 / 796(98.9 \%)$ & $98.9 \% \pm 0.7 \%$ \\
\hline
\end{tabular}

Antibodies detected by EIA. HI and PRN tests.

In contrast to what is related by other authors ${ }^{1.25 .6}$, in this study it was observed that $\mathrm{HI}$ was more sensitive than EIA for detecting low levels of measles antibody. The high cutoff value for EIA could have influenced the sensitivity of this test. Some samples could be classified as positive if the cutoff value was $\mathrm{P} / \mathrm{N} \geq 2.1$.

Low levels of total antibody prevalence were also found with EIA $(73.1 \%)$ and $\mathrm{HI}(82.8 \%)$ tests for the age group 1-4 years old when compared with PRN $(96.3 \%)$ test. These children had low antibody levels detected only when a more sensitive reaction was used. In a smaller proportion this result was observed in other age groups studied. Probably this fact can be due to subclinical reinfections with measles virus during a period of high virus circulation, leading to an increase in antibody levels in older children ${ }^{11.15}$.

In 1987, four months after a mass vaccination campaign against measles conducted in the greater metropolitan region of São Paulo, Brasil, PANNUTI et al. ${ }^{18}$ carried out a seroepidemiological survey including children between one month and 14 years old, irrespective of campaign participation. The antibody prevalence levels for children between $1-14$ years old were $96.6 \%$. values in close agreement with those obtained for this study in the same age group $(99.1 \%)$. Some factors may have contributed for the different results found, among them the sensitivity of the tests employed, indirect immunofluorescence and EIA in the former, and EIA and PRN in the latter.

After the mass vaccination campaign described in this study, a rapid decline in measles incidence rates was observed in Niterói. From June/92 to December/95 only 3 cases among those notified as clinical measles were confirmed by laboratorial tests. The incidence rates of the disease fell from $68,55 / 100,000$ inhabitants in 1991 to $0.89 / 100.000$ in $1994^{\circ}$. These data show that in the municipality studied the strategy based on mass campaign for measles control has succeeded. 
Similar impact in measles incidence was observed in other countries, such as Cuba, English-Caribbean and Suriname ${ }^{3,20}$, which used the same strategy to obtain high coverage levels.

According to CUTTS \& MARKOWITZ ${ }^{3}$ to avoid posthoneymoon outbreaks and, consequently, to control or eliminate measles it is necessary to implement the used strategy adequately. The duration of the benefit achieved will depend on intensive surveillance to investigate all suspect cases and efforts of routine health services to sustain high coverage of new birth cohorts.

\section{RESUMO}

\section{Prevalência de anticorpos contra o vírus do sarampo após campanha de vacinação em massa em Niterói, Estado do Rio de Janeiro, Brasil}

Três meses após a campanha de vacinação em massa (cobertura: $100 \%$, faixa etária: 9 meses a 14 anos) contra o sarampo, um inquérito soroepidemiológico foi realizado em estudantes de um a 19 anos de idade no município de Niterói, estado do Rio de Janeiro. Amostras sangüíneas foram testadas para detecção de anticorpos específicos contra o sarampo por ensaio imunoenzimático (EIE), e os casos negativos testados outra vez utilizando-se a reação de inibição da hemaglutinação (IH) e a neutralização por redução de placas (NP). Das 798 amostras testadas por EIE, $718(90,2 \%)$ foram positivas. A NP foi mais sensível que o EIE e a IH na detecção de anticorpos específicos. A soroprevalência de anticorpos aumentou de $90,2 \%$ para 93,2\% quando a $\mathrm{IH}$ foi empregada em amostras EIE negativas e para $98,9 \%$ quando a NP foi utilizada.

Após a campanha de vacinação em massa, verificouse uma diminuição acentuada na incidência do sarampo no município estudado, demonstrando a efetividade da estratégia utilizada para o controle da doença em países em desenvolvimento.

\section{ACKNOWLEDGEMENTS}

This work would not have been possible without the aid of the health workers from the Municipality of Niterói, State of Rio de Janeiro. The authors thank Drs. W. Bellini and J. Heath from CDC, Atlanta, USA for supplying anti-measles enzyme immune assay.

\section{REFERENCES}

1. BRUNELL. P.A. - Meisles control in the 1990's: measles serology Wld. HIth. Org., 4: 1-34. 1990.

2. CHEN. R.T.: MARCOWITZ. L.E.: AL.BRECTH, P. et al. Reevaluation of protective titers, J. infect. Dis., 162: 1036-1042, 1990.

3. CUTTS. F.T. \& MARKOWITZ, L.E. - Successes and failures in measles control. J. infect. Dis., 170: 32-41. 1994.
4. DABIS, F: WALDMAN, R.J.: MANN, G.F. et al, - Loss of maternal measles antibody during infancy in an African city. Int. J. Epidem., 18: 264-268, 1989

5. DIAZ-ORTEGA, J.L.: FORSEY, T.: CLEMENTS, C.J.\& MILSTIEN J. - The relationship between dose and response of standard measles vaccines. Biologicals, 22: 35-44. 1994.

6. ERDMAN, D.D.: ANDERSON. L.J;:ADAMS. D.R. et al. - Evaluation of monoclonal antibody-based capture enzyme immunoassays for detection of specific antibodies to measles virus. J. clin. Microbiol., 29: 1466-1471, 1991.

7. FUNDAÇÃO INSTITUTO BRASILEIRO DE GEOGRAFIA I ESTATISTICA - Censo Demográfico, 1991

8. FUNDAÇĀO MUNICIPAL DE SAÚdE DE NITERÓI. Superintendências de Ações de Satúde. Departamento de Epidemiologia e Controle de Agravos. Informe Epidemiológico - sarampo. 1992.

9. FUNDAÇÃO MUNICIPAL DE SAÚdE DE NITERÓ. Superintendência de Ações de Sáúde. Departamento de Epidemiologia e Controle de Agravos. Dados Epidemiológicos. 1994

10. FUNDAÇĀO NACIONAL DE SAÚDE (Brasil), - Sarampo: das epidemias rumo à eliminaçĩo. Informe Mensal. Ano VIII. 5. 1-5. 1994.

11. HALSEY. N.A. - The optimal age for administering measles vaceine in developing countries. In: HALSEY, N.A. \& QUADROS. C.A Recent advances in immunization. Washington. Pan American Healıl Organization, 1983.

12. HUMMEL, K.B.: ERDMAN, D.D.: HEATH. J. \& BELLINI. W.J. Baculovirus expression of the nucleoprotein gene of measles virus and utility of the recombinant protein in diagnostic enzyme immunoassilys. J. clin. Microbiol., 30: 2874-2880, 1992

13. KISH. M.G. -Survey Sampling. New York. John Wiley \& Sons. 1965

14. OLIVEIRA, S.A. - Contribuição ao estudo da imunidade contra o sarampo em pessoas vacinadas e não vacinadas nos Municípios de Niterói e São Gonçalo. Rio de Janeiro, 1989 (Tiese de Doutoramento da Faculdade de Medicina da Universidade Federal do Rio de Janeiro)

15. OLIVEIRA, S.A.: HOMMA. A.: CAMILLO-COURA. L. LOUREIRO, M.L.P. \& ALMEIDA. M.T.G.N. - Antimeasles antibodies in children submitted to different vaccination schedules. Rev. Soc. bras. Med. trop., 26: 77-82, 1993.

16. OLIVEIRA, S.A.: SIQUEIRA. M.M.: COSTA. A.I.L.: ALMEIDA M.T.C. \& NASCIMENTO. J.P. - Serological findings during a measles outbreak occurring in a population with a high valceination coverage. Rev. Inst. Med. trop. S. Paulo, 37: 421-425, 1995.

17. OLIVEIRA. S.A.: SOARES. W.N.: DALSTON. M.O.: ALMEIDA M.T.G.N. \& COSTA, A.J.L. - Clinical and epidemiological findings during a measles outbreak occurring in a population with a high vaccination coverage. Rev. Soc. bras. Med. trop., 28: 339-343, 1995

18. PANNUTI, C.S:; MORAES, J.C.; SOUZA. V.A.U.F: CAMARGO M.C.C.; HIDALGO, N.T.R.. AND OTHERS - Measles antibody prevalence after immunization in Sĩo Paulo. Brazil. Bull. WId. Hlth. Org., 69: 557-560, 1991.

19. ROSEN, L. - Hemmagglutination and hemmagglutination-inhibition with measles virus. Virology, 13: 139-141. 1961

20. SMITH, H.; BEYRER, C.; BENONS, L. \& HOSPEDALES, J. Caribbean: measles elimination. Lancet, 338: 563-564. 1991.

Recebido parra publicação em 10/04/1996

Aceito para publicaçĩo em 17/09/1996 